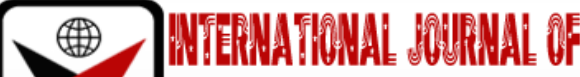

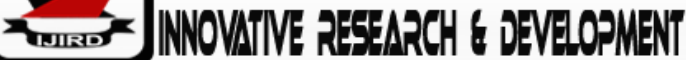

ISSN 2278-0211 (Online)

\section{Philosophy of Taxation and Tax Exemptions of Churches in the Ejisu Municipality of Ghana}

Dr. Alphonsus Beni
Senior Lecturer, Department of Philosophy and Social Sciences,
Spiritan University College, Ghana
Dr. Juliet Banoeng-Yakubo
Lecturer, Warwick Business School,
Warwick University, UK
Bernard Oduro-Amankwaah
Research Assistant, Department of Philosophy and Social Sciences,
Spiritan University College, Ghana

\begin{abstract}
:
In recent years, the practice of tax exemption for churches has become a source of open scrutiny, argument, and controversy on the part of both government and religious leaders. The study attempted to assess the main principles that government base on to impose taxes on its citizenry and to assess the tax exemption status of the churches in Ghana.

Exploratory, descriptive and cross-section surveys were used to investigate and discover from respondent's information on the topic to provide a report on the background, facts, settings and concerns about the principles of taxation and the tax exemption status of churches. The study considered 120 people as its targeted sample of which 114 responded by the use of questionnaires. Also, descriptive analysis such as frequency and percentages were used to analyse the data.

From the information gathered on the research, it was revealed that most Ghanaians representing $65.8 \%$ prefer the government to allocate taxes based on the benefits that taxpayers receive for paying taxes rather than the ability to pay or any other principle for the allocation of taxes. In addition, 57\% of Ghanaians would like the religious organizations to enjoy their tax-exempt status despite allegation by critics that they are amassing wealth for themselves and not contributing to the development of Ghana. Some of the reasons given were that: churches are not profit-making businesses; churches contribute to the development of the nation; churches care for the people more than the government. Some of them concluded that failure to grant the church tax exemption may give room for the churches to engage in business activities. For those with the opposing view, some gave reasons such as: churches have become some sort of commerce; the churches have more money in this world; the payment of taxes by churches may as well boost the revenue of the government. Despite the various arguments, there was an agreement that the Ghana Revenue Authority should check the sales of rosaries, anointing oil, holy water, charge of consultation fees, as these should attract taxation. The paper recommends that Tax-Exempt Division should develop policies and administer taxexempt organizations (including religious organizations) laws. The division should be responsible for exempt organizations tax education and training to enable them understand their tax law obligations. This will improve tax compliance by the exempt organizations.
\end{abstract}

Keywords: Philosophy of taxation, tax exemptions, churches, Ghana

\section{Introduction}

During the past one year, the taxation of churches and religious organizations has become the subject of debate among some Ghanaians. While the question of churches and tax exemption has become a burning issue during the past two decades, it is by no means new to other developed nations like the United States of America.

McGee defines taxation as the "compulsory taking of property by government." A tax, however, is a payment justifiably exacted by authority from part of the community for the benefit of the whole. From whom and in what proportion such a payment shall be required and to what uses it shall be applied, those judgments are made by those to whom government is entrusted. Tiley and Loutzenhiser also state that, "taxes are imposed under the authority of the legislature, levied by a public body, and that they are intended for public purposes."

Taxes are compulsory: it is not a matter of a psychological state of mind, but of an institutional structure. Taxation rests on coercion in the sense that tax evasion is illegal, such that a government would lawfully initiate the use of force if a taxpayer did not comply with his fiscal obligations. It can be said that, he who pays tax without complaining needs to have 
his/her head examined. While businesses and other organizations cannot evade tax without facing the consequences, churches are exempted from paying taxes on their primary income.

Governments all over the world levy tax in order to raise revenue for the provision of public goods, to promote social and economic welfare, to redistribute income and wealth and to promote economic stability.

Taxation, therefore, is used as a mechanism to transfer payments and benefits to the less privileged in the society to promote social justice. It is the duty of the government to stabilize the economy, to prevent high level of inflation and the collapse of business, unemployment and other economic problems. Taxation, therefore, serves as a means of establishing an atmosphere that favours public benefit for the growth of the economy.

The contribution of the churches to the development of the country cannot be ignored. They anticipate and supplement the efforts of the government in building schools, hospitals, orphanages, providing portable drinking water and many more services that are essential. Should the government tax these churches? Could they continue then with these charitable projects? Taxing these churches is to tax all Non-Profit Organizations. The government cannot now afford to lose all the assistance they provide freely. The issue is both dire and complicated.

\subsection{Types of Taxes}

One of the themes in taxation history is the different types of taxes that have been developed and applied by different rulers across different ancient States to raise revenue. These levies ultimately included taxes on property, on the sale of goods, and on inheritances, as well as customs duties. In the reign of King John, he introduced the tax of Scutage which was originally a tax paid in the form of knights sent by a noble landholder to join the king`s army when he required them to fight a war.

Burg comments that a very early and widespread form of taxation was the corvée, which was a form of compulsory labour supplied to the state, generally by the poor, and which lasted even into the nineteenth century in certain countries where people were too poor to pay taxes in any other way.

We must note that, from the earliest times, land was the basis of wealth such that some form of taxation on land or its products seemed an obvious means for rulers or governments to raise revenue. Thus, in Mesopotamia, the earliest form of taxation apparently was the tithe, a collection of a percentage of each landholder's crops. The tithe also became widespread and, in many places, included a tax not only on grains and other crops but also on cattle. Egyptian funerary art dating to the Fifth Dynasty (c. 2390 BC) indicates that the early pharaohs instituted taxes on grains. It is also referred to by the ancient Greek historian Herodotus, in the context of the Lydians offering a tithe of their war booty as tribute to their gods.

The 'Saladin tithe' was introduced in the reign of Henry II to raise funds for the Third Crusade to try to win back Jerusalem from the great Muslim leader, Saladin. Medieval monarchs also obtained a good deal of revenue from the royal forest, especially from courts known as forest eyres, which doled out fines to persons violating the very stringent forest laws.

Other extraordinary revenue such as tallage, was levied on the towns and demesne lands of the Crown; dona or auxilia, taken from Jewish or other money lenders, prelates and religious houses; and a range of different taxes on movable goods and property, levied at various rates, such as a seventh, a thirteenth, a fifteenth, a twentieth, etc., actually continued well beyond the medieval period, into the seventeenth century.

Another type of tax to examine is income tax. Probably the earliest historical mention of income taxes concerns their collection in Egypt in 1580 B.C. At that time, the collection of these taxes was one of the duties of the Grand Vizier. Aristotle is authority for the statement that there was an income tax levied by King Tachus in Egypt upon all employments. These were collected at the suggestion of the Greek general, Chabrais, in the period of about 357 to 390 B. C. There also appears to have been income taxation among the Greeks in the days of Solon (596 B. C.).

Ancient Rome undoubtedly imposed taxation. During the reign of Julius Caesar (49 BC-44 BC) the government of Rome imposed a 1 percent general sales tax in addition to the import duties and other levies that were already being collected. The later Roman Empire, under Augustus and his successors, also exacted a distinctive tax in the form of tribute, payment in money or other form made by rulers of states or provinces that acknowledged their submission to the Empire and thereby bought security and at least some autonomy.

Gibbon mentions that in the time of Constantine the Great (306-337 A. D.) there was evidence of the use of torture in extracting the exact amount of the citizens' income for the purposes of levying taxes thereon. Constantine abolished the use of racks and scourges for this purpose. During the reign of Theodosius (379-395 A. D.), there is reference to this form of taxation in Code Theodosius (1. XIII tit. i. iv.). Gibbon said, "With the view of sharing that species of wealth which is derived from art and labour and which exists in money and merchandise, the emperors imposed a distinct and personal tribute on the trading part of their subjects." Some exemptions were granted in the matter of time and place. An indulgence was also given to the profession of liberal arts. The general income tax upon industry was collected every fourth year and was termed "Lustral Contribution."

Judge Charles D. Rosa, summarizing the ancient taxation says: "The income tax is by no means a new thing. It is as old as the tithes of Biblical times and appeared later in the Roman estimo, the French dixieme, and the English tenth. ..." The exact records of the operation of these ancient tax laws are no longer attainable. It is of considerable interest, however, to note that the political philosophy of early nations recognized incomes as a legitimate field for taxation.

The modern idea of levying taxes based upon income had its inception in England in 1379. This early law was a graduated poll tax based in part upon income. In reality, this was not a poll tax, in the modern application of the term, but was much more logically an income tax. These taxes, general in scope, were applicable to all the members of a given class. Such taxes were imposed during the fifteenth and sixteenth centuries and proved to be of considerable fiscal importance. 
From the modern point of view, the first law governing income taxation by that name went into force in England in January of 1799. This law was passed at the instigation of William Pitt, then Prime Minister and First Lord of the Treasury. A certain part of income was exempt and there were allowances for children and life insurance policies. This earlier law was repealed to make way for Addington's Property and Income Tax of 1803.

The list is almost unending. Burg quotes the critic Sydney Smith who summed it up, in 1820, in an essay in the Edinburgh Review:

Taxes upon everything which it is pleasant to see, hear, smell, or taste. Taxes upon warmth, light, and accommodation. Taxes on everything on earth or under the earth, on everything that comes from abroad or is grown at home. Taxes on the raw material, taxes on every fresh value that is added to it by the industry of man. Taxes on the sauce which pampers man's appetite, and the drug which restores him to health ... on the poor man's salt and the rich man's spice; on the brass nails of the coffin, and the ribbons of the bride: at bed or board; couchant or levant, we must pay.

\subsection{Tax Administration in Ghana}

The British Colonial Government first introduced taxation in Ghana in the then Gold Coast on 1 st November 1943 at the time when the World War II was raging. The tax was an Income Tax Ordinance (Ordinance No. 27 of 1943). It should be noted that before the introduction of income tax in 1943, several attempts had already been made. For instance, in April 1852, the Poll Tax Ordinance was passed to raise money to finance the increased cost of British Administration.

Under the Poll tax Ordinance, every man, woman or child residing in districts under British protection was to pay one shilling (1/-) per head per year. These early experiments of the introduction of direct taxation failed because of weaknesses inherent in the system of collection and the fact that the first proceeds were mainly used to pay the increased salaries of British Official and not for the construction of roads and schools.

The first Income Tax Law, Income Tax Ordinance (N0. 27), 1943 was modelled to a large extent on the general principles underlying the Income Tax Act then in force in the United Kingdom. It imposed the tax generally on incomes having their sources in Ghana so that foreign source income was not liable unless it was remitted in Ghana. One characteristic feature of this Ordinance was the numerous personal reliefs and deductions that it contained.

This ordinance was amended several times. In particular, a very lengthy ordinance, the Income Tax (Amendment) Ordinance 1952 was passed to rectify most of the deficiencies that had been experienced in the previous enactments. In 1961, Act 68 followed by Acts 178 and 197, in 1963, and sealed off by Act 312 in 1965 made drastic amendments to the Consolidated Edition. The second Consolidated Edition was published in September 1966, that is, the Income Tax Decree, 1966 No. 78. The Income Tax Decree 1975, SMCD 5 which was published in December 1975 was the third Consolidated Edition.

A series of amendment to the 1975 Decree made it cumbersome in its usage. One has to grope very patiently through a labyrinth of new provisions in separate enactments to ascertain the current provision. This situation was unavoidable since every annual budget invariable introduced change in tax provisions to amend existing laws.

The introduction of the Internal Revenue Act 2000 (Act 592) finally repealed the SMCD 5 Decree on 1st January 2001. This is the fourth Consolidated Edition. The characteristic feature of Act 592 is that it contains other taxes that were not included in the previous SMCD 5. This is because these taxes are not on income. The taxes concerned are Capital Gains tax ad Gift tax.

On 1 January 2016, the Income Tax Act, 2015, Act 896 came into force repealing Act 592 and saved regulations, notices, and other acts lawfully done under the repealed law. This is the law on taxation of income currently in force.

\subsection{Tax Authority}

In Ghana, the Ghana Revenue Authority Act, 2009 (Act 791) mandates the Ghana Revenue Authority (GRA) to, among others, integrate the collection and management of domestic tax and customs duties, some of which are corporate and personal income, pay as you earn (PAYE), rent, capital gains, gift and dividends, to mention only a few. The Ghana Revenue Authority which was established by the Ghana Revenue Authority Act, 2009 (Act 791) is the sole tax authority with the core mandate to oversee maximum compliance with all relevant laws in order to ensure a sustainable revenue stream for government, trade facilitation and a controlled safe flow of goods across Ghana's borders.

Some of the functions of GRA are to collect taxes, melt out penalties to tax offenders with efficiency, promote tax compliance and education, fight tax fraud and evasion and publish reports and statistics related to revenue collected.

\subsection{Tax Collectors}

The competent authority responsible for direct taxes in Ghana is the Internal Revenue Service, whereas the competent authority responsible for indirect taxes are Customs, Excise and Preventive Service (CEPS) for customs and excise taxes among others, and Value Added Tax (VAT) for value added tax.

\subsection{The Tax Base}

What is actually taxed is referred to as the tax base. There is a variety of different things that can constitute a tax base, namely income or revenue, capital, expenditure or consumption. Income may be in certain circumstances very easy to define. For example, it can be the salary or wages an individual earns as a result of his/her employment. In terms of a business, income is commonly referred to as 'sales revenue' or just revenue' and means the sums generated from sales of the business's products or services. 
However, businesses are allowed to deduct certain costs and expenses from their revenue, to derive an overall profit, and it is this profit that is taxed rather than the actual sales figure. Because income can actually be of many different types, for instance, royalties for an author of books, rental income arising from owning property, it is regarded as very difficult to provide an absolute definition. In Ghana, the Income tax Act, 2015 (Act 896) or the Internal Revenue Act 2000 (Act 592), for instance, does not attempt to do so, preferring to address income by particular type, rather than in general. Nevertheless, it has been regarded to mean a periodic monetary return coming in with some sort of regularity or expected regularity from definite sources. It could thus be received in cash or in kind, that is in forms other than monetary, in which it has to be valued.

There are three categories of income subjected to tax in Ghana. These are employment, business and investment incomes. An individual's income from employment is what individuals gain or profits they make from that employment. This includes any allowances or benefits paid in cash or in kind or given in kind to or on behalf of that individual from employment. An individual`s income from business is that individual`s gains or profits from any business for the year or a part of the year. Business includes any trade, profession or vocation but excludes employment.

The precise meaning of 'capital' depends on the context in which the word is used. In general, it refers to the tangible and intangible assets. For example, land, buildings, equipment, money and investments. Capital assets can increase or decrease in value and may generate income - which is another type of income in addition to those mentioned above. The income may be a profit on selling a particular asset (though assets also can be sold at a loss), or it may be interest on money deposited in a bank or dividends from shares. The income of a person from an investment for a year of assessment is the gains and profits of that person from conducting the investment for the year or a part of the year. These include dividends from a non-resident company, charges on an annuity, rent, royalties, interest and natural resources payment.

Expenditure usually means the amount of their resources (usually expressed in money) that business and individuals pay out for goods and services they need or desire. The idea of consumption may be very similar to expenditure, as one of the meanings of 'expenditure' is 'using up'. However, consumption can also be considered in reference to the destructive use of resources, rather than just the 'trade cycle' idea that is implicit in expenditure. If an item of consumption is taxed, let us say, a box of sugar, by the imposition of a GHC 1.00 duty, then that GHC 1.00 would represent a greater percentage of income for someone earning GHष 1,000.00 than it would for someone earning GHC $10,000.00$. Such a duty or tax is said to be regressive, and it can easily be seen that it might be less equitable to the GHC1,000.00 earner.

However, if the item on which such a tax is imposed is regarded as something that is not necessary for life and health and one has a choice about whether to buy it or not (as one generally would in terms of alcohol), then it is less unfair. Such things can be taken into account when duty levels are set, similar considerations might apply to different types of income.

Taxation is an important form of social cooperation, although the substance of tax policy is a source of continuing conflict. Any group of people that cannot muster resources for collective projects will not be able to act efficaciously as a group and any state that cannot successfully raise revenue will not long survive, says Lindsay.

Taxation might be regarded as a stress assessment for state efficacy. A state unable to collect taxes is probably feeble regardless of its formal powers, and a state that does not need to levy taxes (e.g., one that receives a great deal of money from state-owned natural resources) is in danger of atrophy since its rulers have less need to be concerned with the quality of public administration.

Therefore, any system of taxation must address how tax burdens are allocated among taxpayers. This raises the most fundamental normative questions. On what basis should citizens be taxed? Is it on the ability to pay principles, the benefits principles or any other principle such as the utilitarian principles? What should be the underlying principles of a tax system?

During the Enlightenment period, Adam Smith and his contemporaries and others who lived after him such as Dave Hume, John Locke, Jeremy Bentham, Thomas Hobbes and so forth developed the modern tax theory. The study would consider some of their views on taxation under the principles mentioned above and examine all possible theorists on taxation.

\section{6. "Benefit" Theories/Principles}

'Benefits' theories allocate taxes in proportion to benefits received from the state. The basic fundamental principle of this theory is that taxpayers should pay taxes once they receive benefits from government. If you receive benefits, you should pay for them. In short, "there is no free lunch." Benefits theories explicitly link taxes with spending by considering the fairness of tax burdens in light of the benefits received by the taxpayer from the state. The underlying idea is that of reciprocity: a tax is fair if benefits received from the state at least roughly compensate for the burdens of taxation. This approach seems fair, since any other alternative would be to charge people for the costs of government on some basis other than benefit. Major proponents of the benefit principles are John Locke, Thomas Hobbes, and Samuel Johnson.

\subsubsection{John Locke (1632-1704)}

In his 'social contract theory', a person agrees to abide by the popular decision of a society, in return for the benefits conferred by association of that society, such as protection of life, health, liberty and property. This defends the imposition of taxes.

The basic principle of John Locke`s philosophy is that humans have natural rights to life, liberty, and property. His view on taxation is argued under the natural right to property since the governments grasp property through tax policy. In 
his 'social contract theory', a person agrees to abide by the popular decision of a society, in return for the benefits conferred by association of that society, such as protection of life, health, liberty and property. This defends the imposition of taxes.

In the 'Second Treatise on Government: Of Civil Government,' Chapter XI, "Of the Extent of the Legislative Power," Sections 138 and 140, John Locke argued that the supreme power cannot take from any man any part of his property without his own consent. According to Locke, those who are taxed must also have access to political representation in the form of parliaments. This idea heavily influenced the political philosophies of the founding fathers of America.

Locke's social contract theory legitimated the imposition of taxation through voluntary alienation of individual rights in exchange for state protection of property. This voluntary alienation of rights is Locke's way of reconciling the state's assumption of the right to tax: otherwise, it would be seen as a form of legitimized theft. Therefore, an individual living in a community has, by his decision to live in that community, given consent to the payment of tax for the benefits he derives. Locke is keen to stress that it is only a legitimate government which can impose taxes and can take part of a man's 'estate' in payment. Locke recognizes the need for the state to levy taxes in order to fund its operation.

\subsubsection{Thomas Hobbes (1586-1639)}

Thomas Hobbes felt that levying taxes was justifiable as the price of protection by the state. According to Frecknall-Hughes, Hobbes in his book, Leviathan, indicated that: "the levying of taxes by the state was justifiable as the price paid for security, the rule of law, and indeed, who also developed in some way the idea of a social contract." However, "the institutions of government might not work as they should, and taxation could easily become a power to compel to surrender their property without their consent- a form of 'institutionalized coercion'- especially bearing in mind that there might be a sizeable minority unhappy with a decision implemented by a majority government for which they did not vote. To escape the horns of this particular dilemma, the power to tax must be regarded as limited."

Therefore, taxation, then, is a kind of contract between the state and the individual. It should provide the state with resources for the functions it should discharge, but it cannot be coercive. Citizens by a majority must agree to its imposition. In summary, Hobbes believed that tax should be equated not to a man`s wealth, but to the debt he owed the state for his defense and the maintenance of the rule of law, the latter supported by the military. He also favoured the provision of public support, presumably funded by tax revenues, for those unable to earn a living by their labour.

\subsubsection{Samuel Johnson (1709-1784)}

In the 1770s, Johnson wrote two political pamphlets that have a direct bearing on taxation, namely, The Patriot (1774) and Taxation No Tyranny (1775), both dealing with the issue of American taxation and representation, issues at the centre of the American War of independence. Johnson argued in Lockean terms to defend England's right to tax its American colonies: "that man, therefore, is no patriot, who justifies the ridiculous claims of American usurpation; who endeavours to deprive the nation of lawful authority over its own colonies, which were settled under English protection; were constituted by an English charter; and have been defended by English arms... He that accepts protection stipulates obedience. We have always protected the Americans; we may, therefore, subject them to government."

Johnson returns to the same theme in Taxation No Tyranny: "the colonies are part of Britain, as an arm or leg is a part of a body and the potential independence of America would be like Cornwall setting itself up as an independent country: unthinkable." Hence, those "who flourish under the protection of our government, should contribute something towards its expense." He declares somewhere else, "Of every empire, all the subordinate communities are liable to taxation, because they all share the benefits of government, and, therefore ought all to furnish their proportion of the expense." Johnson does bring to light the practicability of addressing tax issues in Lockean tradition.

\subsubsection{Assessment of the "Benefit" Theories/Principles}

It is difficult to apply the benefit principle in practice in terms of tax policy, as it is difficult to measure the benefit that a taxpayer receives from activities such as education, health, legal system, defense for paying taxes to the government. Moreover, there is the need of another tax principle to allocate tax burdens since the benefit principle seeks to allocate tax burden specifically based on the value a taxpayer receives from the government. In addition, the principle does not redistribute wealth to lower income earners.

A progressive interpretation of the benefits principle would suggest that wealthier taxpayers should pay higher tax rates because they derive the greatest benefit from the existing political order. Low-wage workers derive less benefit from the persistence of the present government because they have little property to protect and could continue to earn subsistence wages under a different political regime. The principle that taxpayers should not be forced to pay more in taxes than the benefits they receive in return therefore seems consistent with funding national defense, the legal system, and other public goods that protect property rights entirely out of taxes on the better off. However, McGee noted that, "some people would pay more than what they get in services while others would pay less. Those who pay more are exploited, while those who pay less are parasites."

\subsection{Analysis of the Philosophy of Taxation}

In conclusion to the analyses of the principle and philosophy of taxation, if the cause for which the tax is needed pertains only to a few, the burden in the first place belongs to these few. Yet, if the primary beneficiaries of the tax are not able to bear the whole burden, then some tax can be required of all others because the members of the body ought to help one another. If it is a common cause or necessity for which the tax revenue is needed, then all should be taxed equally, but based on an equality of geometric proportion so that those who have more should pay more and those who have less 
should pay less. The common burdens should be distributed equally by a formal equality, not by a material equality, which in the end is the greatest inequality.

It is the pursuit of the common good that justifies the State's need for taxation. Johannes Messner understands the principle of the common good in tax and fiscal budgetary policy affecting economic productivity, the economic order generally, the social order, and even cultural tasks. Thus, taxation policy cannot unfairly and needlessly limit economic growth, but it must also respond to the demands of distributive justice.

\section{Materials and Methods}

\subsection{Study Area}

The Ejisu Municipal is one of the 260 Metropolitan, Municipal and District Assemblies (MMDAs) in Ghana, and forms part of the 43 of MMDAs in the Ashanti Region with Ejisu as its administrative capital. The Municipal is known globally for its rich cultural heritage and tourists' attractions notably the booming kente weaving industry. The Municipal stretches over an area of $637.2 \mathrm{~km} 2$ constituting about $10 \%$ of the entire Ashanti Region.

The Municipality is located in the central part of the Ashanti Region and provides enormous opportunity for creating an inland port for Ghana to serve northern section of the country. It is located within longitudes $1^{\circ} 5 \mathrm{~W}$ and $1^{\circ} 39^{\prime}$ $\mathrm{W}$ and latitudes $7^{\circ} 9^{\prime} \mathrm{N}$ and $7^{\circ} 36^{\prime} \mathrm{N}$. It has a large land size of about $1,782.2 \mathrm{sq} . \mathrm{km}$. (690.781sq. miles) and is the fifth largest district in Ashanti region's 30 districts.

Ejisu Municipal shares boundaries with six (6) other Districts in the Region. To the north east and north west of the Municipal are Sekyere East District and Kwabre East Municipal respectively, to the south are Bosomtwe District and Asante Akim South Municipal, to the east is the Asante Akim North Municipal and to the west is the Kumasi Metropolitan. The population of the Municipality according to the 2010 Population and Housing Census stands at 143,762 with 68,648 males 75,114 females.

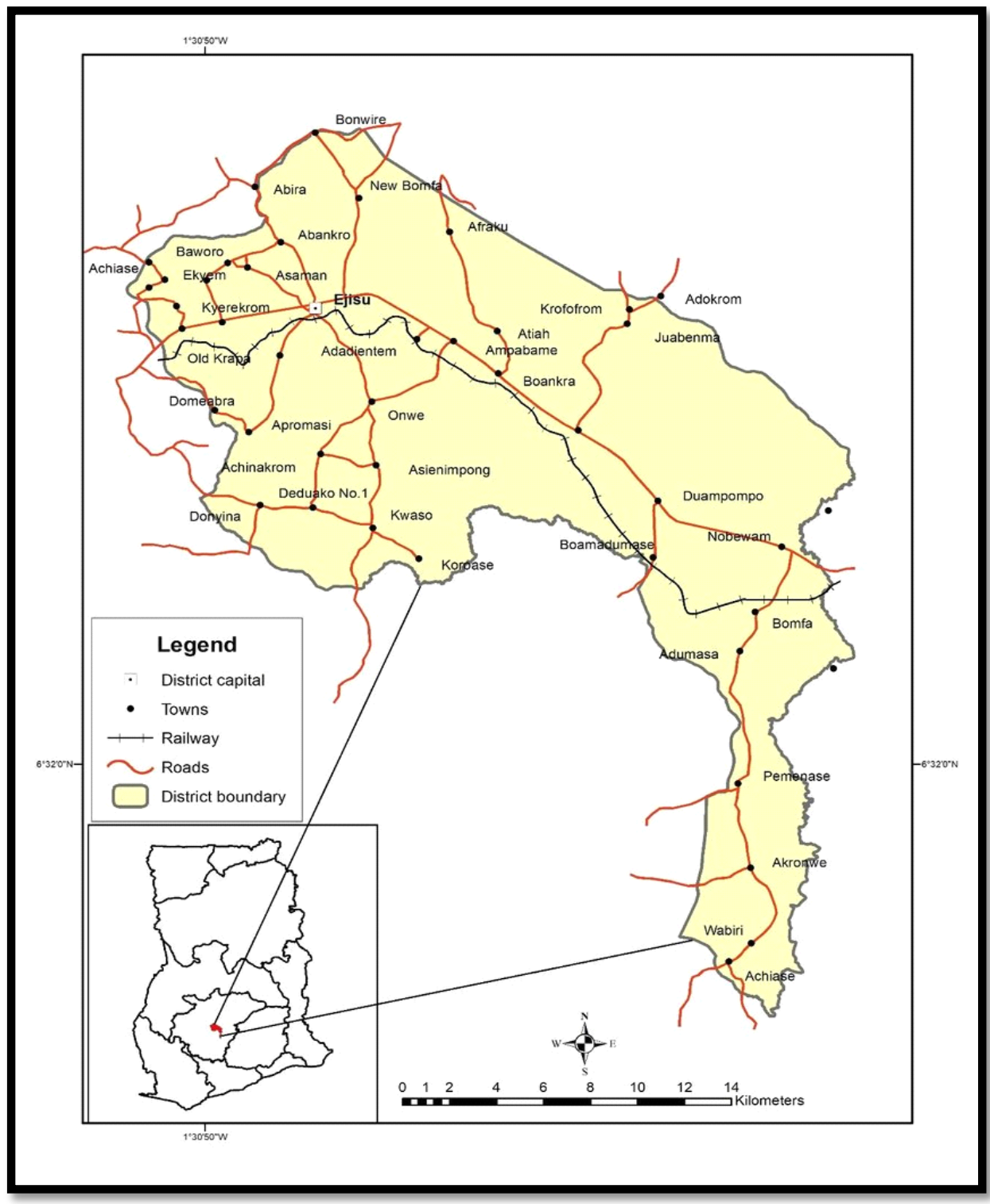




\subsection{Data Types, Sources and Sampling Method}

The study employed the quantitative method approach which involved the collection of data using questionnaires. Relevant data obtained from the field were analyzed using percentages and frequency charts with the use of the Statistical Package for Social Sciences Version 23 (SPSS).

Scholars have written many separate works on taxation, religion and the tax exemptions of the churches and religious organizations. The study turned it focus on assessing the reasons for the imposition of tax and the principle that was employed for the imposition of tax on taxpayers; and to examine the tax exemption status of the churches in Ghana, more particularly, the Ejisu municipality.

Exploratory, descriptive and cross-section surveys were used to discover and investigate from respondent's information on the topic to provide a report on the background, facts, settings and concerns about the philosophy of taxation and tax exemption status of the churches in Ghana.

The study targeted the Catholic parishes, Anglican parishes, Methodist churches, Presbyterian churches, the Pentecostal and Charismatic communities, both organized and individual, pastor-based communities. This was to ensure that the information taking from the field was adequate, accurate and reliable.

According to the argument made by Hair et al. (1998), the question of how large a sample size should be, is unanswered. They are, however, of the belief that based on a large sample distribution concept, reliable approximations can be achieved from samples between 100 to 150 respondents. Thus, the study used one hundred and twenty 120 respondents as its targeted sample.

It was supplemented with secondary data such as the 1992 Constitution of Ghana, the Internal Revenue Act, 2000 (Act 592), the Income Tax Act, 2015 (Act 896), The Income Tax Decree, 1975 (SMCD 5), journals, articles, internet sources and textbooks.

There are two main styles of sampling, probability and non-probability. The research project made used of both the probability and non-probability sampling techniques. In probability samples, all the people within the research population have a chance of being selected. According to Dawson, these types of sample are used if the researcher wishes to explain, predict or generalize information from the whole research population. It follows therefore that simple random sampling was the chosen method. In view of the exploratory nature of the study, purposive sampling was used with regard to the non-probability sampling for in-depth information about the topic. The aim was to generalize about a larger population than it was to gain an in-depth understanding of types.

\section{Presentation of Findings and Data Analysis}

This section presents data collected during the fieldwork, analysis and discussion of major outcomes thereof. The responses obtained through questionnaires are presented in this chapter. As discussed, the targeted sample included 120 questionnaires and, out of this, 114 data replies were received from the field, upon which the analyses were made.

\subsection{Demographic Characteristics of the Respondents}

\subsubsection{Religion Affiliation of the Respondents}

Table 1 shows the religion affiliation of the respondents. Out of 114 respondents, nineteen (19) were Muslims representing $16.7 \%$ of the total respondents, seven (7) were Traditionalists representing $6.1 \%$ of the respondents, two (2) were Atheists representing $1.8 \%$ of the respondents and eighty-six (86) were Christians representing $75.4 \%$ of the respondents. Thus, majority of the respondents are Christians which is consistent with national distribution of religion affiliation of Ghanaians.

\begin{tabular}{|c|c|c|}
\hline Religion & Frequency & Percentage \\
\hline Islam & 19 & 16.7 \\
\hline Traditionalists & 7 & 6.1 \\
\hline Atheist & 2 & 1.8 \\
\hline Christianity & 86 & 75.4 \\
\hline Total & 114 & 100 \\
\hline
\end{tabular}

\subsubsection{Educational Level of the Respondents}

Questions were asked about the educational background of the respondents to help understand how that could influence taxation knowledge in Ghana. Education is a powerful tool for growth of every country; here emphasis is on the formal Education but not on informal Education. 


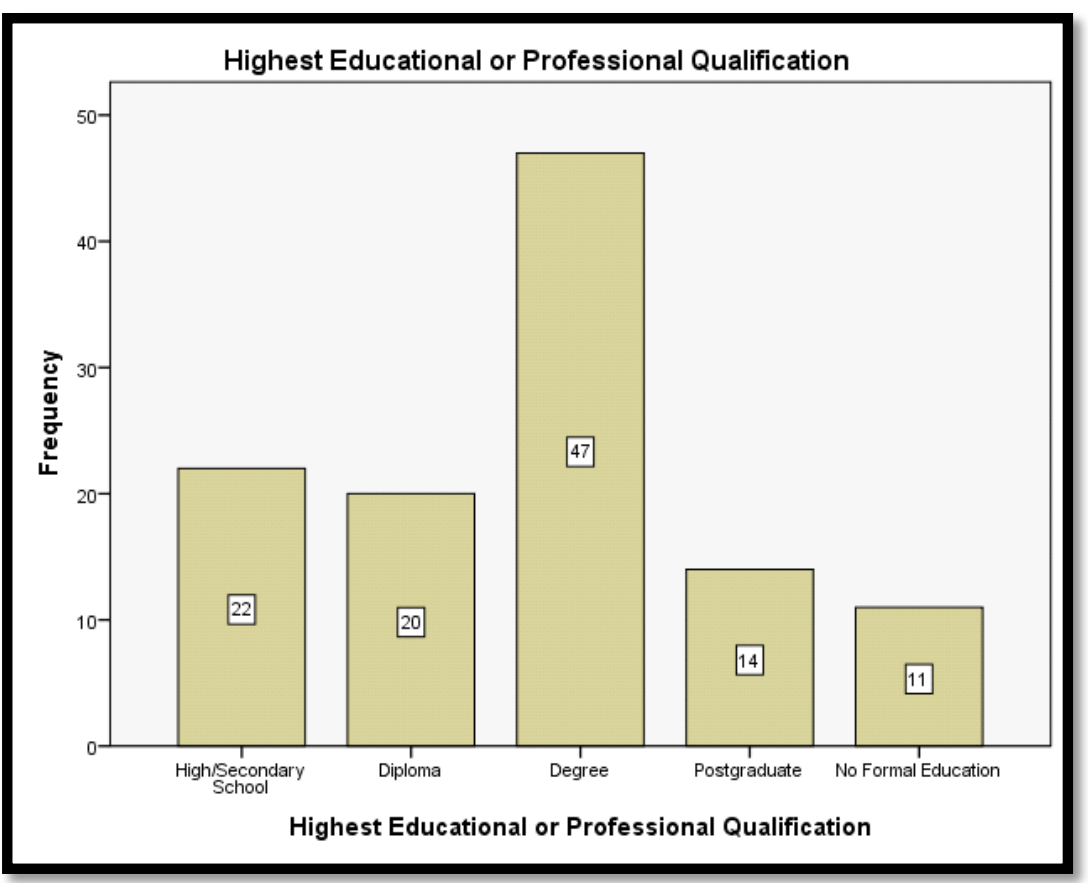

Figure 2: Professional Qualification of the Respondents

Source: Author's Construct Based on Data Obtained from the Field of Study, 2020

The analysis of educational background of the respondents are shown in Figure2 which revealed that out of the 114 respondents, 22 (19.3\%) have High/Secondary school qualification, while 20 (17.5\%) have Diploma qualification. Majority of the respondents, representing $47(41.2 \%)$ have degree qualification, while 14 (12.3\%) have other postgraduate qualifications. Only $13(9.6 \%)$ of the respondents have no formal education. These facts indicate that majority of the respondents are educated and hence should have knowledge about the church taxation and taxation in general. However, this is not the case. When you take out those without formal education, majority of the respondents have average knowledge on taxation, particularly religious organizations tax exemption.

\subsection{Knowledge on Taxation}

This section presents and discusses results on the knowledge of taxation of the sampled respondents in the Municipality. The knowledge on taxation discussed includes the purpose of taxation and principle of taxation.

\subsubsection{Purpose of Taxation}

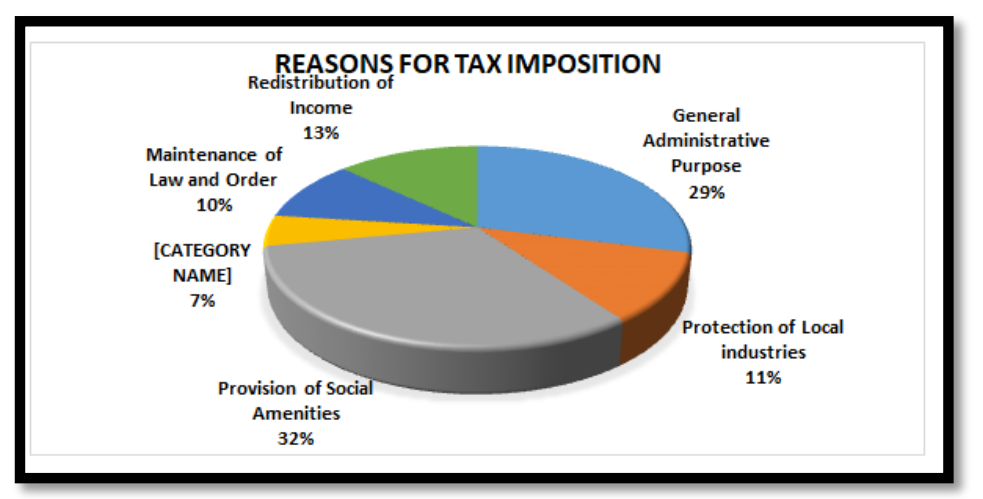

Figure 3: Reasons for Tax Imposition

Source: Author's Construct Based on Data Obtained from the Field of Study, 2020

There are various reasons why governments worldwide impose taxation; it was necessary to know the reasons why Ghana government imposes taxes. This is illustrated in Figure 3. Twenty nine percent of the respondents say that government imposes taxes for general administrative purposes, $11 \%$ were of the opinion that the taxes collected are for the protection of local industries from foreign ones. Thirty two percent of the respondents comprising the majority are of the view that the government imposes taxes in order to provide social amenities for the citizenry, while $10 \%$ says the taxes are collected in order to maintain law and order in the country. This is in support of John Locks 'social contract theory', which states that, a person agrees to abide by the popular decision of a society, in return for the benefits conferred by association of that society, such as protection of life, health, liberty and property. This defends the imposition of taxes. Out of the total respondents, $7 \%$ says the taxes collected are used to correct balance of payment, whereas $13 \%$ are also of 
the view that they are meant for redistribution of income among the citizenry. This is to say that the respondents know the main purpose of taxation.

\subsubsection{Principle of Taxation}

The research project analysed three main principles in taxation: ability to pay principle, benefits principle and the utility principle. The "ability to pay" principle is the principle that the capacity to pay taxes should be measured by the taxpayers' income, consumption, or wealth. The "benefit" principle states that taxpayers should pay taxes once they receive benefits from government. For the Utility principle of taxation, just tax policies are those that maximize aggregate utility.

\begin{tabular}{|c|c|c|}
\hline Principle of Taxation & Frequency & Percentage \\
\hline The ability of the taxpayer to pay taxes & 34 & 29.8 \\
\hline The policy that will utilize maximum satisfaction & 5 & 4.4 \\
\hline The benefit that the taxpayer derives from paying taxes & 75 & 65.8 \\
\hline Total & 114 & 100 \\
\hline
\end{tabular}

Table 2: Principles of Taxation

Source: Author's Construct Based on Data Obtained from the Field of Study, 2020

According to the field study presented in Table 2, 29.8\% of the respondents prefer the ability to pay principle, though $65.8 \%$ supports the benefits principle. However, $4.4 \%$ of the respondents prefer that the government should use the utilitarian principle to determine how it imposes taxes on its citizenry. The majority of the respondents agree with John Locke, Thomas Hobbes, and Samuel Johnson and are therefore willing to pay taxes once they know that they will benefit in return. People do not want to pay tax without knowing what they derive from it. As we have seen, Lindsay confirms this, "a tax is fair if benefits received from the State at least roughly compensate for the burdens of taxation." The principle seems reliable with funding national defense, the legal system, and other public goods that protect property rights entirely out of taxes.

\subsection{Knowledge on Tax Exemptions of Religious Organizations}

This section presents and discusses results on the knowledge of tax exemption of religious organizations of the sampled respondents in the Municipality.

\begin{tabular}{|c|c|c|c|}
\hline Tax exemptions of Religious Organizations & Response Option & Frequency & Percentage \\
\hline Exemption from paying certain taxes & High +very high & 57 & 50 \\
\hline Financial records keeping & Low +very low & 57 & 50 \\
\hline & High +very high & 85 & 74.5 \\
\hline Lransparency, probity and accountability & High +very high & 68 & 25.5 \\
\hline & Low +very low & 46 & 40.3 \\
\hline $\begin{array}{c}\text { Religious organization do not qualify for tax } \\
\text { exemptions }\end{array}$ & High +very high & 67 & 58.8 \\
\hline & Low +very low & 47 & 41.2 \\
\hline
\end{tabular}

Table 3: Ghanaians Knowledge on Tax Exemptions of Religious Organizations

Source: Author's Construct Based on Data Obtained from The Field of Study, 2020

Do Ghanaians know that religious organizations are exempted from paying certain taxes? If the knowledge level is low or high, does the country experience problems in the tax compliance of religious organizations? From the field work illustrated in the Table 3, half of the respondents said they have "High or Very High" knowledge that religious organizations are exempted from paying certain taxes, while the remaining 50\%, expressed "Low or Very low" knowledge in the subject matter. It is not surprising therefore, to find that $58.8 \%$ knows that there are religious organized activities that do not qualify for tax exemption; just $41.2 \%$ does not know this. It is quite comforting to discover that a strong majority of 74.5\% claims that they have "High or Very high" knowledge that religious organizations keep financial records. Only $25.5 \%$, however, expressed a contrary opinion. A higher number of the respondents representing $59.7 \%$ agreed or strongly agreed that religious organizations funds are managed in accordance with the principle of transparency, probity and accountability. Nevertheless, $40.3 \%$ disagreed or strongly disagreed. In general, Ghanaians perceive transparency, probity and accountability in religious organization's financial accounts. 


\subsubsection{Taxes That Religious Organizations Are Exempted from Paying}

\begin{tabular}{|c|c|c|}
\hline Tax Exemptions & Frequency & Percentage \\
\hline All taxes & 8 & 7.0 \\
\hline Business tax & 10 & 8.8 \\
\hline Hospitals, schools & 6 & 5.3 \\
\hline Income tax and business tax & 17 & 14.9 \\
\hline Income tax & 30 & 26.3 \\
\hline No idea & 37 & 32.5 \\
\hline Property tax & 6 & 5.3 \\
\hline Total & 114 & 100.0 \\
\hline
\end{tabular}

Table 4: Taxes Religious Organizations in Ghana Are Exempted from Paying

Source: Author's Construct Based on Data Obtained from The Field of Study, 2020

It was necessary to determine the taxes that religious organizations are exempted from. This enabled the study to determine the extent to which Ghanaians have knowledge about religious organizations taxations system. The Internal Revenue Act, 2000, Act 592, Section 10(1) states, 'the income accruing to or derived by an exempt organization other than income from any business' is exempt from income tax. From the Table 4 however, 7.0\% of the respondents posit that religious organizations are exempted from paying all taxes. That even includes taxes on businesses that yield profits. Others (8.8\%) think that they are exempted from paying taxes on businesses, while 5.3\% says they are exempted from paying taxes on their schools and hospitals. According to the fieldwork, $14.9 \%$ says that they are exempted from both income tax and business tax, despite the fact that other respondents, representing 26.3\% indicates that religious organizations are exempted from paying income tax, which is their primary earnings. Yet still, 5.3\% thinks they are exempted from paying property tax on properties such as Church buildings, hospitals, schools, and business premises. It is quite astonishing that majority (32.5\%) of the respondents do not really know the type of taxes from which religious organizations have exemption even though some claim they know that religious organizations are exempted from paying certain taxes. It can be said that, in general, the majority of Ghanaians do not know the exact taxes from which religious organizations are exempted. Apart from income tax, religious organizations do not pay taxes on any of their quasiinstitutions (schools, orphanages, family homes, hospitals).

Nonetheless, the net income from supposed business activities of a religious organization must be comply with the following three conditions: does the activity constitute a trade or business? Is the trade or business frequently carried on? And is or is not the trade or business substantially related to the organization's exempt purpose? Just because religious organizations use their income from business activities for charitable works does not automatically make the said activities tax exempt. If the activity of a religious organization corresponds to the above conditions, that income should not be subject to tax when: volunteers perform a substantial part of all the work in the operation of the trade or business; the activity is steered by the institution mainly for the expediency of its members; or the trade or business involves the selling of goods, all of which were donated.

\subsubsection{Reasons Why Religious Organizations Are Exempted from Paying Certain Taxes}

\begin{tabular}{|c|c|c|c|}
\hline Reasons & Frequency & Percentage & Valid Percentage \\
\hline Just for the fact that they are religious & 5 & 4.4 & 5.4 \\
\hline Their member pays taxes to the government already & 8 & 7.0 & 8.6 \\
\hline Their work is spiritually based & 5 & 4.4 & 5.4 \\
\hline They are not registered as profit-making business & 33 & 28.9 & 35.5 \\
\hline They are regarded as charitable organizations & 4 & 3.5 & 4.3 \\
\hline $\begin{array}{l}\text { They support the government in the provision of } \\
\text { social amenities and services }\end{array}$ & 38 & 33.3 & 40.9 \\
\hline $\begin{array}{l}\text { Total } \\
\end{array}$ & 93 & 81.6 & 100.0 \\
\hline
\end{tabular}

Table 5: Reasons Why Religious Organizations Are Exempted from Paying Certain Taxes

Source: Author's Construct Based on Data Obtained from the Field of Study, 2020

The study wanted to find out the reason why religious organizations are exempted from certain taxes. As we have seen, prior to the independence of Ghana, churches benefitted from tax exemptions. Varied tax exemptions laws before and after independence exonerated religious organizations from paying income tax. According to Kwasi Nyantakyi, this was in recognition of the contribution these organizations made to society as they prioritized the helping of the poor and needy while lifting up the spiritual welfare of the people. Some of the respondents approve a similar acceptance while others express contrary views.

Data gathered from the field of study presented in Table 5 shows that, out of the 114 respondents, only 93 reacted to this question. $4.4 \%$ of respondents thinks that religious organizations are exempted from paying certain taxes 'just for the fact that they are religious bodies,' and nothing else. This is in line with the $4.4 \%$ and $3.5 \%$ respondents who says that, 'their work is spiritually based,' and 'they are regarded as charitable organizations.' Another group (28.9\%) thinks that 
they do not pay certain taxes because they are not registered as profit making ventures. On the other hand, 33.5\% of the respondents, representing the majority, believe that they support the government in the provision of social amenities and services and that is why they are exempted. About $7 \%$ observes that it is because their members already contribute to the tax burden of the government. It is clear from the data that $18.4 \%$, that is, those who did not answer this question do not know why religious organizations are exempted from paying certain taxes.

\subsection{Should The Government Remove the Tax Exemption Status Enjoyed by Religious Organizations?}

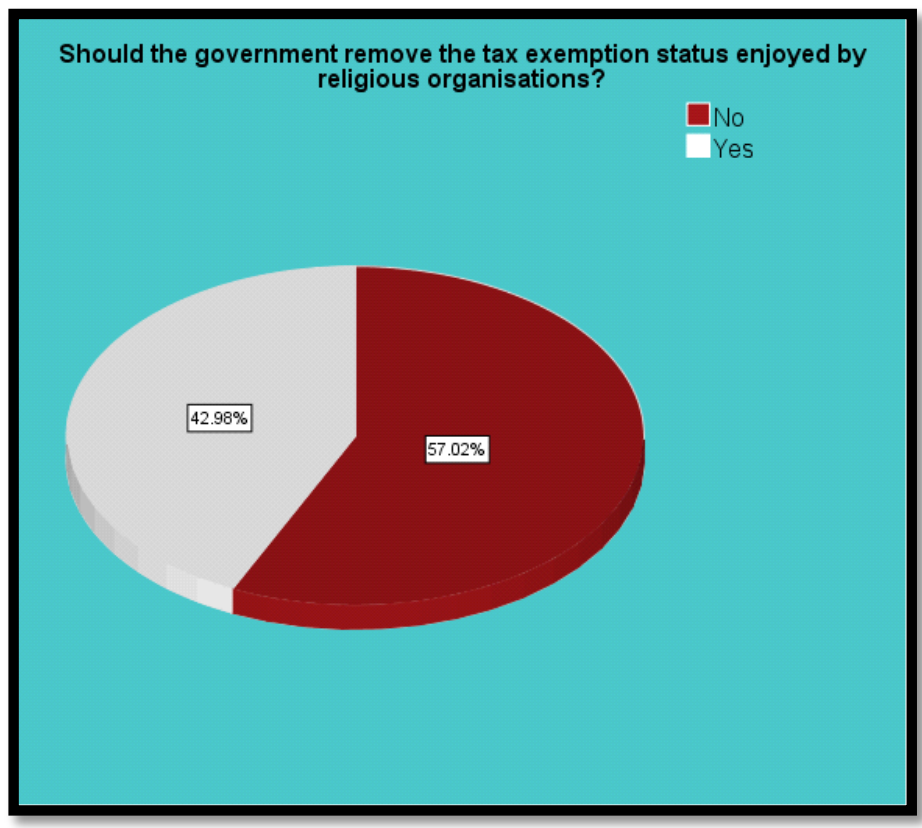

Figure 4: Tax Exemption Status Removal

Source: Author's Construct Based on Data Obtained from the Field of Study, 2020

Respondents were asked the above question and a majority preferred the current law to be left as it is. The majority representing $57.02 \%$ say "no" while the remaining $42.98 \%$ preferred that the exemption should be revoked. This is represented in a Pie chat in Chat $C$. Some of the reasons given by those who responded "no" was as follows: "As long as they do not engage in commercial activities, they should not be taxed; religious organizations are not profit-making businesses; religious bodies contribute to the development of the nation; the church cares for the people more than the government; part of the money they receive are used to set up schools and hospitals. Some said that it will give room for religious organizations to engage in profit making activities."

For those with the opposing view, some gave reasons such as: "church has become some sort of commerce; the purpose of establishment has been misused; the churches have more money in this world; religious institutions are now more like business enterprises with the aim of making profit; the church has become an umbrella for the selling of goods like: water, anointing oil and other commodities free of tax; the payment of taxes by churches may as well boost the revenue of the government; most of these religious organizations do not help the government with the humanitarian needs or support to society."

There are mixed feelings among Ghanaians as to whether or not the government should revoke religious organizations' tax exemptions or to maintain them. Even though a majority of the respondents wants things to be as they are, we must take note that, once the tax exemption status of religious organizations is revoked, that of the nongovernmental organizations must also be revoked. Is the government ready to lose all the contributions made by these religious and non-governmental institutions?

It is important to note, however, the Income Tax Act 2015 (Act 896), Section 97(4) also provides that "the income accruing to or derived by a charitable organization (including churches) is exempt from tax." However, Section 97(5) underscores that, "Subsection (4) does not apply to business income of the charitable organization. Therefore, any attempt to tax churches as churches would be breach of the law as it stands now. Despite the various arguments, there is an agreement that the Ghana Revenue Authority should check the sales of rosaries, anointing oil, holy water, charge of consultation fees, as these should attract taxation.

\subsection{Criteria for Tax Exemption Eligibility}

This section discusses the respondent's views on criteria for tax exemption eligibility. The results are presented in Table 6. 


\begin{tabular}{|c|c|c|}
\hline Tax Exemption Eligibility & Frequency & Percentage \\
\hline If they do not do business for profit & 13 & 11.4 \\
\hline No idea & 46 & 40.4 \\
\hline They are not exempted & 4 & 3.5 \\
\hline When they are registered as a non-profit organization & 25 & 21.9 \\
\hline When they register with the tax authorities & 6 & 5.3 \\
\hline When they render proper accounts to their members & 11 & 9.6 \\
\hline When they support the activities of the government & 9 & 7.9 \\
\hline Total & 114 & 100.0 \\
\hline
\end{tabular}

Table 6: Religious Organizations Eligibility Criteria for Tax Exemption Source: Author's Construct Based on Data Obtained from The Field of Study, 2020

From the results in Table 6, 11.4\% of the respondents were of the view that religious organizations should be eligible for tax exemption if they do not engage in profit making business, while $21.9 \%$ thinks that this exemption is possible when they are registered as non-profit organization. Others (5.3\%) are of the opinion that religious organizations are exempted from certain taxes when they register with the tax authorities. $9.6 \%$ thinks that when they render proper accounts to their members, then, they qualify to enjoy tax exemptions. However, $7.9 \%$ of the respondents opines that religious organizations are eligible for tax exemption when they support the activities of the government, although 3.5\% says categorically that religious organizations should not be exempted from any tax at all. They pay all kinds of taxes in the country. A percentage of 40.4 of the 114 respondents did not know the eligibility criteria for tax exemptions for religious organizations. It can be concluded from the above fact that large relative majority of Ghanaians do not know the eligibility criteria for the tax exemption of religious organizations. As the study have previously examined, the current law on income tax, the Income tax Act, 2015, Act 896, Section 97(2), states that the CG shall, before approving an entity as a charitable organization (including a religious organization), ensure that: (a) The entity is established to operate as a religious institution which is of a public nature. (b) The entity has a written constitution that prohibits that entity from: (i) engaging in a party-political activity, supporting a political party or using its platform to engage in party politics; (ii) any function other than operating as a religious institution; and (iii) conferring a private benefit, other than in pursuit of a function of the entity as a religious institution. It can be seen from the historical analysis that, for an organization to be exempted from paying income tax, it should be religious in nature, have a public character and it must also have a written constitution.

\subsection{The Bottlenecks and Shortcomings of the Existing Constitutional, Institutional and Administrative System of the Taxation} of Religious Organizations.

This section reveals results on the respondents' views on bottlenecks in the constitutional, institutional and administrative system of the taxation of religious organization. The results are presented in Table 7.

\begin{tabular}{|c|c|c|}
\hline Bottlenecks & Frequency & Percentage \\
\hline $\begin{array}{c}\text { Fear of religious recrimination makes lawmakers avoid matters } \\
\text { pertaining to religion }\end{array}$ & 4 & 3.5 \\
\hline $\begin{array}{l}\text { GRA are not mandated by law to audit the financial records of } \\
\text { the churches }\end{array}$ & 5 & 4.4 \\
\hline Improper record keeping of financial accounts by the churches & 8 & 7.0 \\
\hline Inadequate laws to regulate the activities of the churches & 18 & 15.8 \\
\hline Lack of education on church taxation & 23 & 20.2 \\
\hline Lack of supervision from the Ghana Revenue Authority & 28 & 24.6 \\
\hline Some churches do not register their businesses & 5 & 4.4 \\
\hline $\begin{array}{l}\text { The churches are not obliged to present their financial accounts } \\
\text { to the public }\end{array}$ & 5 & 4.4 \\
\hline $\begin{array}{l}\text { The GRA does not verify the non-profit nature of church } \\
\text { activities }\end{array}$ & 4 & 3.5 \\
\hline $\begin{array}{l}\text { Total } \\
\end{array}$ & 100 & 87.7 \\
\hline Missing & 14 & 12.3 \\
\hline Total & 114 & 100.0 \\
\hline
\end{tabular}

Table 7: The Bottlenecks and Shortcomings of the Existing Constitutional, Institutional and Administrative System of Religious Organization Taxation

Source: Author's Construct Based on Data Obtained from the Field of Study, 2020

To find out about the restrictions and shortcomings of the existing constitutional, institutional and administrative systems of religious organization taxation from the fieldwork, respondents gave different views. This is demonstrated in Table 7. It should be noted that $12.3 \%$ of the respondents left this question unanswered. Out of the total respondents, $3.5 \%$ are of the opinion that, "fear of religious recrimination makes law makers avoid matters pertaining to religion." $4.4 \%$ cited that it is because "GRA are not mandated by law to audit the financial records of the churches." 7\% of respondents think it is as a result of "improper record keeping of financial accounts by the churches," while $15.8 \%$ say that it is because of 
"inadequate laws to regulate the activities of the churches." A percentage of 20.2 of the respondents says that it is because of "lack of education on church taxation," and a relative majority of $24.6 \%$ thinks that there is "lack of supervision from the GRA." $4.4 \%$ says that some of the tax anomalies occur because "some churches do not register their businesses" in order for them to be taxed. Another 4.4\% of the respondents are of the view that "the churches are not obliged to present their financial accounts to the general public". As a result, they are not audited. Only 3.5\% of the respondents have the opinion that "GRA does not verify the non-profit nature of church activities"; thus, some churches operate businesses without paying taxes. This shows that there is a lot of work to be done by GRA on religious organizations taxation.

\section{Summary of Findings}

The purpose of the study was to investigate the reasons for the imposition of tax and to look at the principles that should be used to account for the imposition of tax; and to examine the tax exemption status of religious organizations in Ghana, more particularly, in the Ejisu municipality.

The following were the main findings of the study. From the research, it was discovered that, respondents have high knowledge on general taxation but average knowledge when it comes to the system of taxation of religious organizations. Majority of the respondents prefer the benefit to pay principle of imposing taxes rather than the ability to pay principle, though it is not seen as a just and equitable system of taxation.

Majority of the total respondents were males. This indicates that males dominate in the area of taxation in the municipality. The educational backgrounds of a greater percentage of members were above diploma and degree level. As a result, majority of them have at least, an average level of knowledge of taxation in general. Nevertheless, this does not contribute to an adequate knowledge in the taxation of religious organizations. On average, the respondents lack the necessary knowledge to understand the tax-exempt status of religious organizations. Moreover, most of the respondents want religious organizations to continue enjoying their tax-exempt status.

The study also revealed that, majority of the respondents have high knowledge about the reasons for the imposition of taxes. They were of the view that, governments impose taxes in order to generate revenue to provide basic social amenities for the citizenry. Furthermore, the study discovered that, majority of the taxpayers are willing to pay taxes once they know that they will benefit in return. People do not want to pay tax without knowing what they derive from it. This shows that respondents are willing to comply with and contribute to the tax requirement once they know they will receive benefits in return.

Another finding of the study indicates that only half of the respondents have very high or high knowledge that religious organizations are exempted from paying certain taxes but are not exempted from all taxes imposed by the government, while the other half do not know that religious organizations are exempted from paying certain taxes. It could be said that even though an average Ghanaian has knowledge of the tax-exempt status of religious organizations, the majority of Ghanaians do not know the exact taxes that religious organizations are exempted from paying.

The results also revealed that most Ghanaians know well that, religious organizations keep financial records and, in general, pursue transparency, probity and accountability in a religious organization's financial accounts. The results also show that majority of Ghanaians know why religious organizations are exempted from paying certain taxes. Only few Ghanaians have no knowledge about the reason or reasons why they are exempted from paying certain taxes.

Moreover, the study discovered that, majority of the respondents have no idea about the eligibility criteria for the tax exemption of religious organizations. Some respondents expressed their views but they were not in agreement with what is stipulated in the laws of the country. Therefore, a large majority of Ghanaians do not know the eligibility criteria for the tax exemption of religious organizations.

Furthermore, from the research findings, majority of the respondents would like the tax exemption status given to religious organizations by the State to remain as it is and should therefore not be revoked because of the expressed concerns of a minority.

Findings from the study also point out that, majority of the respondents have the view that the inadequacies and shortcomings of the existing constitutional, institutional and administrative system of taxation for religious organizations are because of lack of education about the taxation of religious organizations and lack of supervision from the Ghana Revenue Authority to enforce tax laws.

\section{Recommendations}

After assessing the philosophy of taxation and the tax exemption status of religious organizations in Ghana, specifically, in the Ejisu Municipality, the researcher believes that certain measures can make religious organizations comply with their taxation system thereby raising more tax revenue for the government. Here are some recommendations to solve some of the injustices in taxation, inadequacies and shortcomings of the existing constitutional, institutional and administrative system of taxing religious organizations in Ghana.

The study recommends that tax burden should be distributed according to capacities of the individual to pay and not the benefit that one receives. The rich should pay a greater ratio of their income and wealth for taxes. A proportional distribution of the tax burden based on the ability to pay is the ethical standard that should rule. Distributive justice requires a proportionate and progressive allocation of the tax burden. Yet such taxation should not work against the common good in a fair fiscal productivity and distribution allocation. The State, through its taxing system, can and should work to serve its primary finality of being for all.

A 'Tax-Exempt Division' in the GRA is essential. There should be a Director of the division who reports to the Commissioner of the GRA. The Tax-Exempt Division should develop policies and administer tax-exempt organizations (including religious organizations) laws. The Director must be responsible for planning, managing, supervising and 
executing national GRA activities in the realm of exempt organizations. The division should be responsible for exempt organizations tax education and training to enable them understand their tax law obligations. This will improve tax compliance by the exempt organizations.

Furthermore, to safeguard against financial abuses of religious organizations and tax-exempt organizations in general, the government, through the GRA, should be mandated by an act of parliament to audit the exempt organizations to ensure that they are not unlawfully engaging in activities subject to taxation. The audit should include review of books, records, and other data to advance all significant issues, to ensure a correct determination of eligibility of exempt status. The basis of all good financial and revenue activity is punctual and accurate registration of movements of money. Tax exempt organizations should be held responsible for upkeep of good standards.

Nonetheless, Parliament should pass an Act for religious organization audit procedures in order to protect religious organizations against impermissible government interference with their religious rights, while also permitting the GRA to determine whether a religious organization has engaged in activities that are subject to taxation.

The Ghana Revenue Authority should issue programmes that will help educate the existing leaders of religious organizations and incoming leaders on their tax responsibilities. Their education should also extend to the entire Ghanaian populace. This will help increase tax compliance in the country.

\section{Conclusion}

The study attempted to investigate the main principles that government applies to impose taxes on its citizenry and to assess the tax exemption status of religious organizations in Ghana.

From the information gathered on this study, it was shown that most Ghanaians prefer the government to use the benefit to pay principle to determine the taxes for the people. However, this principle will favour the rich more than the poor in the society. Tax burden should be distributed according to capacities of the individual to pay and not the benefit that one receives. The rich should pay a greater proportion of their income and wealth as taxes. A proportional allocation of the tax burden based on the ability to pay is the ethical principle that should rule. Tax revenues should go to help the poor. Churches must enact the option for the poor in the country by recognizing and assisting the State in its obligation to ensure that the poor have the minimum necessities for a decent human existence. The overall tax burden in any just system of taxation should be low.

The principles of the common good and distributive justice must establish the benchmarks for adjudicating the justice of distributing the tax burden based on proportional equality. The individual in society does not have exclusive claims to what he or she owns since the individual is part of the social whole to which one is related. What the individual owes is determined by proportional equality and not by some arithmetic equality.

The study also revealed that most Ghanaians have a sufficient knowledge of taxation. They are aware of the reasons for the imposition of taxes. When it comes to taxing religious organizations, it is not so encouraging. Half of the respondents claim to have knowledge of the exempt status of religious organizations. Nevertheless, they do not know the eligibility criteria for a religious organization to qualify for tax exemption. As a result, there is low compliance in religious organizations' tax compliance.

The majority of Ghanaians would like the exempt status enjoyed by the religious organizations to be continued, despite allegation by critics that they are amassing wealth for themselves and not contributing to the development of the country as they used to. Majority of the respondents believe that some of the religious organizations are still helping the poor and assisting the government in the provision of basic social amenities.

The research project also showed that, some of the respondents were of the view that, there was lack of education and training about religious organizations' tax law obligations and lack of supervision and monitoring by the Ghana Revenue Authority. This leads to low compliance on tax laws that apply to religious organizations.

\section{References}

i. Addallah, Ali-Nakyea. Taxation in Ghana: Principles, Practice and Planning. Accra: Black $\quad$ Mask Limited, 2006.

ii. Agalega, Evans. Taxation in Ghana. Koforidua: Ziphin Business World, 2015.

iii. Aharoni, Yohanon. The Land of the Bible. Translated by A. F. Rainey. London: Burns and Oates, 1967.

iv. Allami, Abdullah Wahib. "Principalizing Islamic Zakat as a system of taxation." PhD diss. Brunel University London, 2016. http://bura.brunel.ac.uk/handle/2438/12238

v. ___ "Zakat as Islamic Taxation and its Application in the Contemporary Saudi Legal System." Journal of Islamic State Practices in International Law 5 (2009).

vi. AlGhofeeli A. Nawazel AlZakat (The New Issues of Zakat). Riyadh: AlMaiman and Bank AlBilad, 2008.

vii. Ancient Facts and Fictions Concerning Churches and Tithes. Macmillan And Company, 1888.

viii. Armstrong, Karen. Islam: A Short History. London: Phoenix Press, 2009.

ix. Azmi, Sabahuddin. Islamic Economics. India: Goodword Books, 2004.

x. Bagus, Philipp, Walter Block, Marian Eabrasu, David Howden, and Jérémie Rostan. "The ethics of tax evasion." Business and Society Review 116, no. 3 (2011): 375-401.

xi. Breasted, James H. Ancient Records 2. University of Chicago, 1906-1907.

xii. Brown, Raymond E. The Churches the Apostles Left Behind. Ramsey, NJ: Paulist Press, 1984.

xiii. Burg, David F. A World History of Tax Rebellions: An Encyclopedia of Tax Rebels, Revolts, and Riots from Antiquity to the Present. London: Routledge, 2004.

xiv. Burner, Johann K. Theory of Equitable Taxation. Berlin: Springer-Verlag, 1989. 
xv. Calvin, John. Commentaries on the Epistle to the Romans. Translated by John Owen. Grand Rapids: Wm. B. Eerdmans Publishing Company, 1959.

xvi. ___ Institutes of the Christian Religion. Translated by Henry Beveridge. Grand Rapids: Wm. B. Eerdmans Publishing Company, 1957.

xvii. Cronin, John, ed. Social Principles and Economic Life. Milwaukee: Bruce Publishing Co., 1964.

xviii. Crowe, Martin Timothy (Rev). "The Moral Obligation of Paying Just Taxes." The Catholic University of America Studies in Sacred Theology, no. 84, (1944).

xix. Curran, Charles E. "Just Taxation in the Roman Catholic Tradition." The Journal of Religious Ethics 13, no. 1 (Spring 1985): 113-133. https://www.jstor.org/stable/40015003.

xx. David Hume. "Of Civil Liberty." Essay 11. In Essays, Literary, Moral, and Political. London: Ward, Lock, \& Co., [1741] 1875.

xxi. de Vaux, Roland. Ancient Israel: Its Life and Institutions. Translated by John McHugh. New York: McGraw-Hill, 1961.

xxii. Dimopoulos, Thomas. "Theories and Philosophy of Property Taxation." Neapolis University institutional repository (2015). Hephaestus Repository. Accessed September 24, 2019. http://hdl.handle.net/11728/6273

xxiii. Dome, Takuo. The Political Economy of Public Finance in Britain, 1767-1873. London: Routledge, 2004.

xxiv. Ekelund Jr, Robert B and Douglas M. Walker. "J. S. Mill on the Income Tax Exemption and Inheritance Taxes: The Evidence Reconsidered." History of Political Economy 28, no. 4 (1996)

xxv. Finnis, John. Aquinas. Oxford University Press, Oxford, 1998.

xxvi. Fitzmyer, Joseph A. The Gospel According to Luke I-IX. New York: Doubleday, 1981.

xxvii. Frecknall Hughes, Jane and Lynne Oats. "King John's Tax Innovations-Extortion, Resistance, and the Establishment of the Principle of Taxation by Consent." Accounting Historians Journal 34, no. 2 (2007): $75-107$.

xxviii. Frecknall Hughes, Jane. "Re-examining King John and Magna Carta: Reflections on Reasons, Methodology and Methods." In Making Legal History: Approaches and Methodologies, edited by Anthony Musson and Chantal Stebbings. Cambridge: Cambridge University Press, 2012.

xxix. __ The Theory, Principles and Management of Taxation: An Introduction. London: Routledge, 2014. BookSee. en.booksee.org/book/2258136

xxx. Garnan, A. Bryan, ed. Black's Law Dictionary, 8th edition. USA: St. Paul Minn West Publishing Co., 2004.

xxxi. Gibbon, Edward. History of the Decline and Fall of the Roman Empire, 1838.

xxxii. Gilson, Etienne ed. The Church Speaks to the Modern World: The Social Teachings of Leo XIII. Garden City, NY: Doubleday Image Books, 1954.

xxxiii. Green, Ronald M. "Ethical Issues in Taxation."12-25 in The Future of Tax Policy in New Hampshire. Durham, NH: University of New Hampshire Center for Educational Field Services, 1983.

xxxiv. Gremillion, Joseph ed. The Gospel of Peace and Justice: Catholic Social Teaching since Pope John. Maryknoll, NY: Orbis Books, 1976.

xxxv. Heichelheim, Fritz M. An Ancient Economic History I, 2nd. Leiden: A. W. Sijthoff's, 1958.

xxxvi. Herodotus (1989) Histories, Books I-II, Locb edn.i

xxxvii. Idris, Aliyu S U R Mansur and Amina A. Ismail, eds. "Readings in Islamic Economics." International Institute of Islamic Banking and Finance (2013).

xxxviii. Jacques, Michael J. G. Adam Smith's Philosophy on Taxation. Johannesburg: Association for Incentive Revenue Research, No.6, October 1987.

xxxix. Jagersma, Hendrik. “The Tithes in the Old Testament.” Oudtestamentische Studien 21 (1981): 116-128.

xl. James, Simon R. A Dictionary of Taxation. 2nd ed. Cheltenham: Edward Elgar Publishing, 2012

xli. Johnson, Samuel. Taxation No Tyranny: An Answer to the Resolutions and Address of the American Congress, in The Works of Samuel Johnson, Vol. 14, Troy, New York, Pafraets \& Company, 1913(1775): 93-144. Accessed September 5, 2019. http://www.samueljohnson.com.

xlii. ___ The Patriot. In The Works of Samuel Johnson 14. Troy and New York: Pafraets \& Company, ([1774] 1913). Accessed September 23, 2019. http://www.samueljohnson.com.

xliii. Josephus, Flavius. Jewish Antiquities, 1926, XVI.

xliv. Kaplow, Louis. The Theory of Taxation and Public Economics. Princeton: Princeton University Press, 2008.

xlv. Keith, Blair S. "Praying for a Tax Break: Churches, Political Speech, and the Loss of Section 501(C)(3)." Tax Exempt Status, 86 no. 2, February 14, 2009.

xlvi. Khalaaf, A. Koulasat Tareekh AlTashri'i AlIslami. Kuwait: Dar AlKalam, 1970.

xlvii. Kobetsky. Michael. Internal Taxation of Permanent Establishment: Principles and Policy. New York: Cambridge University Press, 2011

xlviii. Lewis, Naphtali. Life in Egypt under Roman Rule. Oxford: Clarendon Press, 1983.

xlix. Lindsay, Ira K. "The Ethics of Tax Policy." In The Routledge Handbook of Ethics and Public Policy. Edited by Annabelle Lever and Andrei Poama. New York: Routledge, 2019.

l. Locke, John. The Second Treatise of Government $1690 \mathrm{~b}$

li. Lugo, Johannes De Disputation 36, 8 Vols. Paris, 1869.

lii. Luther, Martin. Luther's Works. Edited by Jaroslav Pelikan and Helmut T. Lehmann I. St. Louis: Concordia Publishing House and Philadelphia: Fortress Press, 1955.

liii. McGee, W. Robert. "Is tax evasion unethical"? University of Kansas Law Review 42, no.2 (1993): 411

liv. ___ The Philosophy of Taxation and Public Finance. Boston: Kluwer Academic Publishers, 2004. 
lv. McLaughlin, Terence P. ed. The Church and the Reconstruction of the Modern World: The Social Encyclicals of Pope Pius XI. Garden City, NY: Doubleday Image Books, 1957.

lvi. Messner, Johannes. Social Ethics: Natural Law in the Western World. St. Louis: B. Herder, 1965.

lvii. Metzger, Charles R. "Brief History of Income Taxation." American Bar Association Journal 13, no. 11 (November 1927):662-667 Accessed September 30, 2019. https://www.jstor.org/stable/25707292.

lviii. McEleney, Neil J. "Matthew 17: 24-27-Who Paid the Temple Tax? A Lesson in Avoidance of Scandal." Catholic Biblical Quarterly 38 no. 2 (April 1976):188-192. Accessed September 30, 2019. https://www.jstor.org/stable/43714171

lix. Michael, Martin, J. "Should the Government Be in the Business of Taxing Churches," Regent University Law Review 29 (2016): 307-336.

lx. Mill, John Stuart. Testimony before the Select Committee on Income and Property Tax 1861 (the Hubbard Committee), House of Commons. Vol. 2 of British Parliamentary Papers, National Finance: Income Tax. Shannon: Irish University Press, 1968-69.

lxi. ___ Testimony before the Select Committee on Income and Property Tax 1852, House of Commons. Vol. 1 of British Parliamentary Papers. National Finance: Income Tax. Shannon: Irish University Press, 1968-69.

lxii. ___ Principles of Political Economy, 1848. Edited by W. J. Ashley. New York: Kelley, 1965.

lxiii. Montesquieu De V Esprit des Lois, 1848. In Metzger, "Brief History of Income Taxation."

lxiv. Musson, Anthony and Chantal Stebbings, eds. Making Legal History: Approaches and Methodologies. Cambridge: Cambridge University Press, 2012.

lxv. Nanji, Azim A. "Ethics and Taxation: The Perspective of the Islamic Tradition." The Journal of Religious Ethics 13, no. 1 (Spring, 1985): 161-178. Accessed September 30, 2019.https://www.jstor.org/stable/40015005.

lxvi. Noth, Martin. "Numbers: A Commentary." The Old Testament Library. Philadelphia: Westminster, 1968.

lxvii. Kwasi Nyantakyi Owiredu. "Taxation of religious organizations: The position of the law and related matters." My Joy Online. September 10, 2018. www.myjoyonline.com.

lxviii. Oden Jr., Robert A. “Taxation in Biblical Israel.” The Journal of Religious Ethics 12, no. 2 (Fall, 1984 ): $162-181$. Accessed September 30, 2019. https://www.jstor.org/stable/40014982

lxix. Olokooba, Saka Muhammed. Nigerian Taxation Law, Practice and Procedures Simplified. Singapore: Springer, 2019. Accessed September 24, 2019. https://doi.org/10.1007/978-981-13-2607-3

lxx. P. Laslett ed. Locke's Two Treatises of Government: A Critical Edition with Introduction and Notes, 2nd ed. Cambridge: Cambridge University Press, 1970.

lxxi. Pheme, Perkins. "Taxes in the New Testament." The Journal of Religious Ethics 12, no. 2 (Fall, 1984):182-200. Accessed September 30, 2019. https://www.jstor.org/stable/40014983

lxxii. Philo. The Special Laws (De Specialibus Leges). In Loeb Classical Library, Philo, vol. 7. Cambridge, MA: Harvard University Press, 1937. 97-641.

lxxiii. Pope John XXIII. Mater Et Magistra. Encyclical (May 15, 1961). Accessed February 23, 2020. http://www.papalencyclicals.net/John23/j23mater.htm

lxxiv. Pope John Paul II. "Discours à des Conseillers Fiscaux." November. 7, 1980. La Documentation Catholique 78. (January 4)

lxxv. Pope Leo XIII. Rerum Novarum. Encyclical (May 15, 1891). Accessed February 23, 2020. http://www.papalencyclicals.net/Leo13/l13rerum.htm

lxxvi. Rosen, Harvey S. Public Finance, $5^{\text {th }}$ ed. Pennslyvania: Irwin/McGraw-Hill, 1999.

lxxvii. Ryan, John A. "A Program of Social Reform by Legislation.” The Catholic World 89 (1909).

lxxviii. Schwarz, Catherine M., ed. The Chambers Dictionary. Chambers Harrap Publishers Limited, 1993.

lxxix. Shriver Jr, Donald W and E. Richard Knox. "Taxation in the History of Protestant Ethics." The Journal of Religious Ethics 13, no. 1 (spring, 1985):134-160. Accessed September 30, 2019. https://www.jstor.org/stable/40015004.

lxxx. Slemrod, Joel. “On the high-income Laffer curve.” Tax progressivity and income inequality 177, 1994.

lxxxi. Sodjah, Doris "Taxes: The Hope and Future of National Development." Accessed September $12,2019$. http://www.ghana.gov.gh/index.php/media-center/features/4165-taxes-the-hope-and-future-of-national development.

lxxxii. Smallwood, Mary E. The Jews under Roman Rule: From Pompey to Diocletian. Leiden: Brill, 1976.

lxxxiii. Thompson, William G. "Matthew's Advice to a Divided Community (Mt. 17: 22-18: 85)." Analecta Biblica 44. Rome: Biblical Institute Press, 1970.

lxxxiv. Tiley, John, and Glen Loutzenhiser. Revenue law: introduction to UK tax law; income tax; capital gains tax; inheritance tax. Oxford: Hart Publishing, 2012.

lxxxv. Ubayd, Abu. Kitab al-Arnwal. Beirut: Darul- Kutub, Al-Ilmiyyah, 1986.

lxxxvi. Weber, Max. Ancient Judaism. Edited and Translated by Hans H. Gerth and Don Martindale. New York: Free Press, 1952.

lxxxvii. "What did John Locke think about taxation?" eNotes Editorial. November 17, 2015. Accessed September 13, 2019. https://www.enotes.com/homework-help/what-did-john-lock-think-about-taxation-556969.

lxxxviii. Whitehead, John W. "Tax Exemption and Churches: A Historical and Constitutional Analysis," CUMB. Law. Review 22. (1992): 524-529

lxxxix. William Bill, ed. The New Webster's Comprehensive Dictionary of English Language. American International Press New York, 1993. 
xc. Williams W. David and Geoffrey Morse. Davies Principles of Tax Law, 6th ed. London: Sweet and Maxwell, 2008.

xci. Wilson, Prichard and Isaac Bentum. "Taxation and development in Ghana: Finance, Equity and Accountability." Tax Justice Countries Report Series, Ghana Report, 2009.

xcii. Witte, John Jr. "Tax Exemption of Church Property: Historical Anomaly or Valid Constitutional Practice?" S. CAL. Law. Review 664 (1991) 